\title{
15. ORGANIC SEDIMENTATION IN CELEBES AND SULU BASINS: TYPE OF ORGANIC MATTER AND EVALUATION OF ORGANIC CARBON ACCUMULATION RATES ${ }^{1}$
}

\author{
Philippe Bertrand, ${ }^{2}$ Ulrich Berner, ${ }^{3}$ and Elisabeth Lallier-Vergès ${ }^{2}$
}

\begin{abstract}
This study relates the organic sedimentation characteristics to the lithostratigraphic successions that were observed at Site 767 (Celebes Sea) and Site 768 (Sulu Sea) during ODP Leg 124. It is based on the total organic carbon content (TOC) of the sediments, on the petrographic type and maturity of the organic matter, and on the TOC accumulation rates calculated for the lithostratigraphic units.

In the Celebes and Sulu Seas sediments, the organic matter is mainly of terrestrial origin with the highest concentrations and TOC accumulation rates occurring in the middle Miocene turbiditic sequences that correspond to a major compressive event between the Philippine Mobile Belt and the Palawan, Cagayan, and Sulu Ridges.

Petrographic analysis of the Eocene and lower Miocene organic matter in the Celebes Sea shows that it consists only of highly degraded terrestrial particles. This observation and the very low TOC accumulation rates indicate poor conditions for organic carbon preservation during this open-ocean phase of the Celebes Basin formation. The organic matter, either of marine or terrestrial origin, is much better preserved in the younger sediments, suggesting physico-chemical changes in the depositional environment. Because of the dilution phenomena by turbidites, it is difficult to observe the progressive improvement of the organic matter preservation throughout the turbiditic series. The same change in preservation is broadly observed in the Sulu Sea from the early Miocene (rapid opening phase of the basin with massive pyroclastic deposits) to the present.
\end{abstract}

\section{INTRODUCTION}

The objectives of Leg 124 of the Ocean Drilling Program were to determine the age and stratigraphy of the Celebes and Sulu Seas, which are thought to record the history of complex tectonic and oceanographic events that have battered this western Pacific region throughout the Cenozoic. The present study attempts to relate the organic sedimentation characteristics to the lithostratigraphic successions recorded at Sites 767 (Celebes) and 768 (Sulu). The total organic carbon content (TOC) data have been previously published in Rangin, Silver, von Breymann et al. (1990), whereas the results concerning the petrographic type and state of preservation of the organic matter, and the evaluation of TOC accumulation rates are reported in this paper.

\section{SAMPLES}

Samples were taken from the two main boreholes drilled during the Leg 124 cruise, i.e. the Sites 767 (Celebes Sea) and 768 (Sulu Sea). These boreholes were drilled in the deepest part of each basin to obtain the best sedimentary record and to avoid influences from the basin margins or ridges (Rangin, Silver, von Breymann et al., 1990).

The total organic carbon (TOC) determinations were carried out on board the ship using the Rock Eval II (Explanatory Notes chapter in Rangin, Silver, von Breymann et al., 1990). One sample was taken per core, either at the top or at the bottom of a section just after cutting the liner. In addition, samples were taken for petrographic investigations, approximately one each $10 \mathrm{~m}$ in the upper part of the sedimentary column down to $50 \mathrm{~m}$ below seafloor (mbsf), then approximately one each $50 \mathrm{~m}$ down to the basement.

\footnotetext{
${ }^{1}$ Silver, E. A., Rangin, C., von Breymann, M. T., et al., 1991. Proc. ODP, Sci Results, 124: College Station, TX (Ocean Drilling Program)

${ }^{2}$ Unité de Recherche en Pétrologie Organique, URA 724 du CNRS, Université d'Orléans, 45067 Orleans Cedex 2, France.

${ }^{3}$ Bundesanstalt für Geowissenschaften und Rohstoffe, Stilleweg 2, $3000 \mathrm{Han}-$ nover 51, Federal Republic of Germany.
}

\section{METHODS}

\section{Type and Maturity of Organic Matter}

The pyrolysis parameters of the Rock Eval (Hydrogen Index, Oxygen Index, $T_{\max }$ ) were not considered for organic matter typing because of the low TOC values of the sediments from both sites, generally < $1 \%$ (Rangin, Silver, von Breymann et al., 1990). In addition, the Rock Eval parameters characterize the organic matter as a whole, so that it is sometimes difficult to distinguish the respective influences of the genetic type and of the preservation degree in the observed variations. For these reasons, we chose to characterize the type of organic matter using a petrographic approach.

The petrographic analysis consisted of observations of isolated kerogen by transmitted light microscopy and by scanning electron microscopy (SEM), as reported for Leg 117 studies (Bertrand et al., 1991). Qualitative chemical determinations were carried out using an energy dispersive spectrometer (EDS) coupled with SEM. The kerogen was observed at two stages of the isolation procedure. In a first step, the $\mathrm{HCl}-\mathrm{HF}$ treatment leads to a residue containing organic matter, metallic sulfides (mainly pyrite), and some fine minerals that have survived the acid treatment either because of their association with amorphous matter or because of their mineralogical nature ( $\mathrm{Ti}$ minerals). This residue is called total residue (TR). In a second step, the TR was submitted to additional $\mathrm{KOH}$ and $\mathrm{HNO}_{3}$ treatments, followed by a densitometric separation $(d<2,2)$, leading to the second residue (SR). This latter residue was composed almost exclusively of organic matter, sometimes still containing fine pyrite crystals. Generally, pyrite framboids and massive crystals and other minerals are entirely removed during this step. Semiquantitative evaluations that are given in Table 1 are based on the observation of SR in transmitted-light microscopy. All general descriptions and comments take into account observation of both TR and SR. The residues were described and evaluated using four main categories of components: amorphous organic matter (AOM), lignaceous organic matter (LOM), other structured elements including spores, pollen, cuticles, algae (OSE), and pyrite. 
Table 1. Total organic carbon content (TOC) and petrographic results from Site 767 and Site 768 samples (Celebes Sea). AOM = amorphous organic matter $(\%)$, LOM = lignaceous organic matter $(\%)$, OSE $=$ other structured elements $(\%), R_{\mathrm{m}}=$ mean vitrinite reflectance value $(\%)$, pyrite: * rare, ${ }^{* *}$ frequent, ${ }^{* * *}$ abundant.

\begin{tabular}{|c|c|c|c|c|c|c|c|}
\hline $\begin{array}{l}\text { Core, section } \\
\text { interval }(\mathrm{cm})\end{array}$ & Mbsf & TOC & $\mathrm{AOM}$ & LOM & OSE & Pyrite & $R_{m}$ \\
\hline \multicolumn{8}{|l|}{ Sample 124-767A. } \\
\hline $1 \mathrm{H}-1,23-28$ & 0.23 & 0.59 & 40 & 30 & 30 & - & \\
\hline $1 \mathrm{H}-\mathrm{CC}, 11-16$ & 3.9 & 0.45 & 60 & 20 & 20 & • & \\
\hline \multicolumn{8}{|l|}{ Sample 124-767B. } \\
\hline $2 \mathrm{H}-1,43-48$ & 9.43 & 0.73 & 80 & 10 & 10 & $*$ & \\
\hline $3 \mathrm{H}-1,12-17$ & 18.62 & 0.39 & 70 & 25 & 5 & 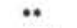 & \\
\hline $4 \mathrm{H}-1,10-15$ & 28.1 & 0.79 & 55 & 43 & 2 & $\cdots$ & \\
\hline $5 \mathrm{H}-1,10-15$ & 37.6 & 0.38 & 80 & 20 & & $\cdots$ & 0.34 \\
\hline $6 \mathrm{H}-1,20-25$ & 47.2 & 0.22 & 70 & 28 & 2 & $\cdots$ & \\
\hline $10 \mathrm{H}-5,95-97$ & 87.95 & 0.25 & 90 & 10 & & $* *$ & 0.31 \\
\hline $19 X-1,15-20$ & 167.75 & 0.30 & 95 & 5 & & & 0.37 \\
\hline $22 X-1,18-23$ & 193.68 & 0.28 & 50 & 50 & & $\cdots$ & \\
\hline $25 \times-4,76-78$ & 228.16 & 0.05 & 15 & 75 & 10 & $\cdots$ & \\
\hline $25 \times-5,0-3$ & 228.9 & 0.23 & 90 & 5 & 5 & $*$ & 0.37 \\
\hline $30 \times-1,27-29$ & 271.27 & 0.21 & 70 & 15 & 15 & $* *$ & 0.41 \\
\hline $35 \times-1,69-71$ & 320.09 & 0.11 & 45 & 45 & 10 & $\cdots$ & \\
\hline $39 \times-4,89-92$ & 363.49 & 0.17 & 95 & 5 & & $\cdot$ & 0.28 \\
\hline $40 \times-3,134-136$ & 372.14 & 0.07 & 25 & 75 & & $\cdots$ & \\
\hline $40 \times-4,0-3$ & 372.3 & 0.21 & 28 & 2 & 70 & $\cdots$ & 0.47 \\
\hline $45 X-C C, 28-31$ & 425.88 & 0.12 & 25 & 70 & 5 & $*$ & 0.38 \\
\hline $45 \mathrm{X}-\mathrm{CC}, 49-52$ & 446.88 & & 10 & 80 & 10 & • & \\
\hline $50 X-3,24-28$ & 467.34 & 0.10 & 60 & 35 & 5 & 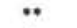 & 0.30 \\
\hline $54 \mathrm{X}-3,80-82$ & 506.3 & 0.65 & 0 & 99 & 1 & • & 0.53 \\
\hline $60 \times-2,30-33$ & 561.6 & 0.64 & 0 & 95 & 5 & - & \\
\hline $60 \times-2,100-103$ & 562.32 & 2.75 & 0 & 99 & & - & \\
\hline $60 X-3,13-16$ & 562.93 & 4.99 & 1 & 99 & & - & \\
\hline $60 \times-3,70-73$ & 563.5 & 0.25 & 1 & 95 & 4 & - & 0.39 \\
\hline $60 \times-3,90-93$ & 563.7 & 2.93 & 0 & 99 & & - & \\
\hline $60 \times-5,19-23$ & 565.99 & 0.75 & 0 & 95 & 5 & - & \\
\hline $61 \times-2,30-34$ & 571.2 & 0.73 & 1 & 90 & 9 & • & \\
\hline $61 X-3,112-116$ & 573.52 & 0.39 & 1 & 99 & & $* *$ & \\
\hline $70 \times-5,79-81$ & 662.79 & 0.46 & 1 & 95 & 4 & $\cdots$ & 0.41 \\
\hline $72 \times-4,90-93$ & 680.7 & 0.08 & 0 & 98 & 2 & & 0.39 \\
\hline $75 \dot{X}-1,127-129$ & 705.47 & 0.14 & 0 & 99 & 1 & & \\
\hline \multicolumn{8}{|l|}{ Sample $124-767 C$. } \\
\hline $8 R-1,67-71$ & 743.97 & & 1 & 99 & & & \\
\hline \multicolumn{8}{|l|}{ Sample $124-768 \mathrm{~A}$ - } \\
\hline $1 \mathrm{H}-1,40-45$ & 0.42 & 0.06 & 1 & 90 & 9 & - & \\
\hline $1 \mathrm{H}-4,40-45$ & 4.95 & 0.05 & 10 & 90 & & & \\
\hline \multicolumn{8}{|l|}{ Sample 124-768B- } \\
\hline $4 \mathrm{H}-6,90-95$ & 31.42 & 0.40 & 90 & 10 & & $\cdots$ & 0.31 \\
\hline $13 \mathrm{H}-1,65-67$ & 109.15 & 0.06 & 25 & 70 & 5 & & \\
\hline $15 \mathrm{H}-2,18-21$ & 129.2 & 0.39 & 45 & 55 & & $*$ & \\
\hline $18 \mathrm{H}-1,100-105$ & 157.02 & 0.28 & 70 & 25 & 5 & * & \\
\hline $20 \mathrm{H}-5,28-30$ & 180.09 & 0.28 & 70 & 30 & & - & 0.36 \\
\hline $28 \mathrm{X}-1,108-113$ & 239.7 & 0.45 & 20 & 50 & 30 & $* * *$ & 0.33 \\
\hline $33 \times-1,56-59$ & 287.37 & 3.85 & 30 & 65 & 5 & $* *$ & \\
\hline $33 X-2,130-134$ & 289.62 & 0.49 & 2 & 95 & 3 & $*$ & \\
\hline $38 \times-4,87-90$ & 337,49 & 0.25 & 15 & 80 & 5 & $* * *$ & 0.36 \\
\hline \multicolumn{8}{|l|}{ Sample $124-768 C$ - } \\
\hline $1 R-3,113-115$ & 357.34 & 1.51 & 1 & 98 & 1 & $* *$ & \\
\hline $6 \mathrm{R}-2,20-23$ & 403.12 & 0.61 & $i$ & 89 & 10 & $\cdots$ & 0.44 \\
\hline $11 R-5,0-3$ & 455.6 & & 40 & 60 & & $*$ & 0.54 \\
\hline IIR-5, 15-17 & 455.76 & 1.11 & 1 & 95 & 4 & $*$ & \\
\hline $17 R-3,143-147$ & 511.95 & 1.21 & 0 & 98 & 2 & * & 0.55 \\
\hline $17 R-4,49-53$ & 512.51 & 0.60 & 0 & 100 & & - & \\
\hline $18 R-4,62-66$ & 522.34 & 0.46 & 20 & 78 & 2 & - & \\
\hline $18 R-4,70-74$ & 522.42 & 0.19 & 10 & 90 & & - & \\
\hline 23R-1, 92-94 & 566.43 & 0.30 & 50 & 45 & 5 & - & \\
\hline $23 \mathrm{R}-1,104-106$ & 566.55 & 0.44 & 20 & 70 & 10 & • & 0.58 \\
\hline $29 \mathrm{R}-4,13-16$ & 628.15 & 0.48 & 70 & 25 & 5 & $\cdots$ & 0.67 \\
\hline $32 \mathrm{R}-3,32-34$ & 655.73 & 0.08 & 2 & 95 & 3 & • & \\
\hline $33 \mathrm{R}-2,94-98$ & 664.56 & 0.37 & 10 & 85 & 5 & - & 0.66 \\
\hline $34 \mathrm{R}-5,17-21$ & 677.99 & 0.38 & 20 & 75 & 5 & * & \\
\hline 35R-5, 0-3 & 687.4 & & 30 & 70 & & & 0.63 \\
\hline $39 R-4,24-27$ & 724.95 & 0.04 & 10 & 90 & & $* * *$ & \\
\hline $41 \mathrm{R}-5,0-3$ & 745.6 & 0.19 & 20 & 80 & & • & 0.86 \\
\hline $45 \mathrm{R}-3,0-3$ & 780.7 & 0.11 & 5 & 95 & & & 0.84 \\
\hline $49 \mathrm{R}-1,52-54$ & 816.03 & 0.00 & 5 & 95 & & - & \\
\hline 50R-1, 2-4 & 825.23 & 0.04 & 5 & 95 & & & \\
\hline $50 R-3,55-57$ & 828.76 & 0.04 & 0 & 100 & & & \\
\hline $63 \mathrm{R}-6,0-3$ & 957.8 & 0.03 & 0 & 100 & & & \\
\hline $69 \mathrm{R}-4,149-150$ & 1014.29 & 0.08 & I & 99 & & & \\
\hline
\end{tabular}

Thermal evolution of the organic matter was carried out using the vitrinite reflectance method (International Handbook of Coal Petrography, 1963, 1971, 1975). For this purpose the vitrinite particles were concentrated from the whole samples by a density treatment and then prepared as polished sections. The measurements were made using a Leitz MPVII microphotometer.

\section{Evaluation of TOC Accumulation Rates}

The accumulation rates, either of sediment or of TOC, were calculated on the basis of mean values for each lithostratigraphic unit. The TOC accumulation rates were obtained from the formula (Emeis and Kvenvolden, 1986):

$$
\text { TOC acc. rate }\left[\mathrm{g} / \mathrm{cm}^{2} \cdot 1000 \psi \rho\right]=\text { TOC } \cdot[[\mathrm{WD}-(1.025 P)] / 100] \cdot S
$$

where

TOC is the total organic carbon content (\%),

WD is the wet-bulk sediment density,

1.025 is the mean density of pore water,

$P$ is the porosity of the wet-bulk sediment,

and $S$ is the sediment accumulation rate $(\mathrm{cm} / 1000 \mathrm{yr})$.

This calculated TOC accumulation rate represents the residual TOC accumulation rate resulting from the deposition processes as well as the weight loss due to diagenetic processes. The possible diagenetic losses depend on both the nature of the organic matter and the thermal history of the sediments (early and thermal diagenetic effects).

The previous formula was applied for each lithostratigraphic unit based on the mean value of each parameter. These values, the number of individual values on which the mean was calculated (n), and the standard deviation (sd), are reported in Table 2 . The age of the unit limits were calculated on the basis of a linear interpolation between the two nearest known limits of biozones (Rangin, Silver, von Breymann, et al., 1990). The general correlation of the biozones and the absolute time scale is based on the scheme given by Berggren et al. (1985).

\section{RESULTS AND DISCUSSION}

\section{Type of Organic Matter at Site 767 (Celebes Sea)}

The petrographic analysis of the organic matter allowed the identification of several organic facies units for each Site. These units are probably subdivided in subunits, but boundary identification was limited by the intervals between petrographic samples. The results for Site 767 are described below and listed and shown as semiquantitative evaluations in Table 1 and Figure 1, respectively.

The organic facies Unit A ( 0 to $480 \mathrm{mbsf}$ ) is characterized by minor to strongly dominant marine amorphous organic matter (P1. 1.1), sometimes diluted by strong to dominant terrestrial input. The terrestrial material is composed of lignaceous fragments ( $\mathrm{Pl}$. 2.1 ), cuticles fragments (Pl. 1.3), spores and pollen grains, and fungus filaments in the lower part. Additionally, rare planktonic and benthic microfossils (algae, chitinous microforaminifers; Pl. 1.1 and 1.2) and zooclasts (scolecodonts) are also present. The level of pyritization is moderate to strong, mainly appearing as framboids associated within the amorphous organic matter. This organic facies unit corresponds approximately to the lithostratigraphic Units I to IIIA (Fig.1), mainly characterized as volcanogenic clayey silt to silty claystone (Units I to IIC) and by hemipelagic claystone (Unit IIIA). The observed fluctuations between AOM and LOM are partly due to the presence of interbedded carbonate turbidites or siltstone turbidites and depend on the position of the samples within the sediment structures. Indeed, this is shown for the case of the Samples 124-767B-40X-3, 134 $136 \mathrm{~cm}$, and -767B-40X-4, 0-3 cm, respectively, located just over 
Table 2. Mean values of the parameters used for the TOC accumulation rate evaluation for the different lithostratigraphic units or subunits at Site 767 (Celebes Sea) and Site 768 (Sulu Sea). Age = age of the unit limits (m.y.), TOC = mean value for TOC $(\%)$, WD = mean value for the wet-bulk sediment density, porosity $=$ mean value for the wet-bulk sediment porosity $(\%), s d=$ standard deviation, $n=$ number of individual measured values, sed acc rate $=$ mean value for the residual sediment accumulation rate (including compaction effect) in $\mathrm{cm} / 1000 \mathrm{yr}$, TOC acc rate $=$ mean value for the residual TOC accumulation rate (including diagenetic weight loss effect) in $\mathrm{mg} / \mathrm{cm}^{2} \cdot 1000 \psi \rho$.

\begin{tabular}{|c|c|c|c|c|c|c|c|c|c|c|c|c|c|}
\hline Unit & $\begin{array}{l}\text { Depth } \\
\text { (mbsf) }\end{array}$ & Age & TOC & nTOC & sd TOC & WD & nWD & sd WD & Porosity & n Porosity & sd Porosity & $\begin{array}{l}\text { Sed } \\
\text { acc } \\
\text { rate }\end{array}$ & $\begin{array}{l}\text { TOC } \\
\text { acc } \\
\text { rate }\end{array}$ \\
\hline \multicolumn{14}{|l|}{ Site 767} \\
\hline I & $0-56.8$ & $0-0.71$ & 0.38 & 7 & 0.14 & 1.36 & 15 & 0.02 & 83.10 & 14 & 1.77 & 8 & 15.5 \\
\hline IIA & $56.8-109.6$ & $0.71-1.98$ & 0.45 & 4 & 0.27 & 1.42 & 9 & 0.04 & 77.60 & 9 & 3.40 & 4.16 & 11.6 \\
\hline IIB & $109.6-300.1$ & $1.98-5.15$ & 0.23 & 19 & 0.20 & 1.57 & 38 & 0.11 & 69.80 & 38 & 6.30 & 9.4 & 18.3 \\
\hline IIC & $300.1-406.5$ & $5.15-8.2$ & 0.24 & 11 & 0.15 & 1.70 & 21 & 0.22 & 64.00 & 21 & 12.00 & 3.5 & 8.8 \\
\hline IIIA & $406.5-484.4$ & $8.2-9.34$ & 0.58 & 7 & 0.26 & 1.87 & 19 & 0.28 & 52.20 & 19 & 14.00 & 6.8 & 52.4 \\
\hline IIIB & $484.4-573.7$ & $9.34-11.24$ & 0.87 & 10 & 0.63 & 1.92 & 13 & 0.35 & 42.00 & 13 & 14.70 & 4.7 & 60.9 \\
\hline IIIC & $573.7-698.9$ & $11.24-22.37$ & 0.11 & 15 & 0.05 & 2.06 & 27 & 0.22 & 47.10 & 27 & 10.80 & 1.12 & 1.9 \\
\hline IV & $698.9-786.6$ & $22.37-41.7$ & 0.18 & 12 & 0.08 & 2.11 & 23 & 0.10 & 46.00 & 23 & 4.40 & 0.45 & 1.3 \\
\hline \multicolumn{14}{|l|}{ Site 768} \\
\hline I & $0-123$ & $0-2.12$ & 0.06 & 19 & 0.09 & 1.43 & 50 & 0.08 & 83.50 & 24 & 3.05 & 5.80 & 2.00 \\
\hline II & $123-652.4$ & $2.12-9.79$ & 0.43 & 72 & 0.48 & 1.98 & 147 & 0.22 & 49.90 & 147 & 12.10 & 6.90 & 43.60 \\
\hline III & $652.4-806.65$ & $9.79-16.9$ & 0.22 & 19 & 0.18 & 2.16 & 43 & 0.16 & 39.90 & 43 & 6.71 & 2.20 & 8.50 \\
\hline IV & $806.65-1003.6$ & $16.9-18.3$ & 0.01 & 23 & 0.02 & 2.07 & 45 & 0.09 & 34.70 & 45 & 3.94 & 14.10 & 2.40 \\
\hline V & $1003.6-1046.6$ & $18.3-18.7$ & 0.03 & 6 & 0.04 & 2.14 & 11 & 0.10 & 27.00 & 11 & 4.16 & 10.10 & 5.60 \\
\hline
\end{tabular}

and below the starting surface of a turbidite. The first sample is characterized by a low TOC and by a high proportion of LOM, while the second sample is characterized by a higher TOC and by a low proportion of LOM.

The organic facies Unit B (480 to $670 \mathrm{mbsf}$ ) is dominated by the terrestrial input ( $\mathrm{Pl} .1 .5$ and 1.6), mainly including strongly pyritized lignaceous fragments (fine crystals and framboids). Rare, probably reworked, small lignaceous fragments, very rare fusinite fragments (terrestrial organic matter oxidized before de- position), rare spores and pollen grains and fungus filaments (P1. 1.6) are also present. Because of its color and texture, most of the rare to very rare amorphous organic matter is thought to have a terrestrial origin as well (lignaceous fragments, the structure of which would have been destroyed through bacterial activity). This organic facies unit corresponds to the lithostratigraphic Units IIIB and IIIC (Fig. 1) characterized by a mixing of turbidites and hemipelagic claystone levels interbedded. The turbidites are dominant in Unit IIIB (turbidite claystone, silty claystone, quartz

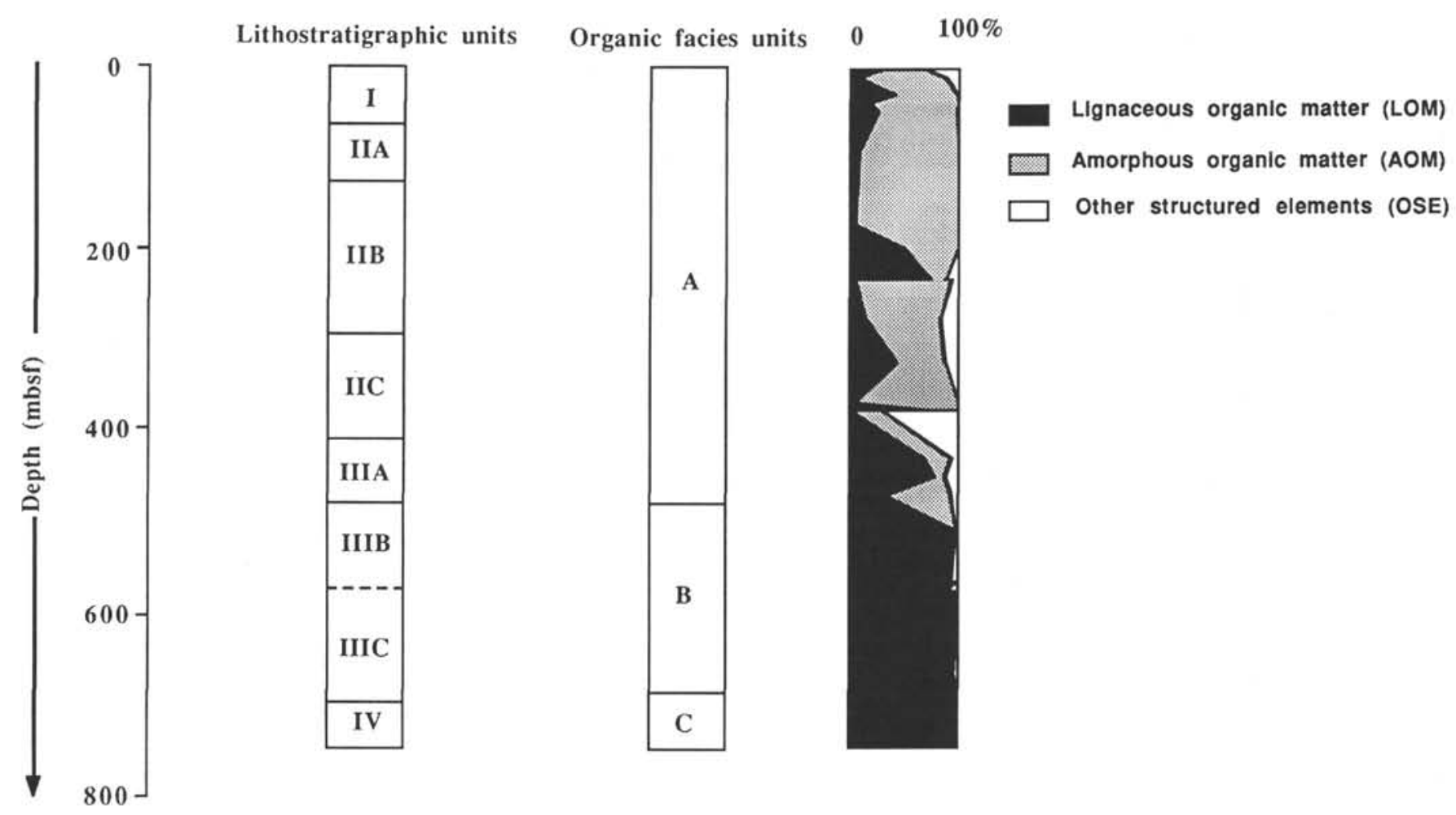

Figure 1. Organic facies units in comparison with the lithostratigraphic units at Site 767 (Celebes Sea). 
siltstone, and sandstone). A number of them were macroscopically observed associated with lignitic material, notably in core $60 \mathrm{X}$ in which several samples were taken. In these neighboring levels, the petrographic composition of the organic matter appears relatively homogeneous, while the TOC concentrations range from $0.25 \%$ to $5 \%$. Therefore it is probable that the TOC variations have been induced by selective deposition between the mineral and organic materials during a turbiditic event while the composition of the initially reworked sediment has been constant.

The organic facies Unit C (670 to $750 \mathrm{mbsf}$ ) is strongly dominated by terrestrial input, mainly including degraded small lignaceous fragments (Pl. 1.7 and 1.8) and very rare spores and pollen grains. There is no or only very weak pyritization. This organic facies unit corresponds approximately to the lower part of the lithostratigraphic Unit IIIC and to Unit IV (Fig.1), which is composed of brown to reddish-brown pelagic claystone. The type of organic matter as well as the TOC values (Fig. 2) do not reveal the Unit IV/Unit IIIC Boundary. This probably indicates that the degradation of the organic material occurred before deposition. Indeed, such degraded particles are known to be relatively inert with respect to the diagenetic processes, and therefore they would have been unaffected by the pelagic to hemipelagic transition.

\section{Type of Organic Matter at Site 768 (Sulu Sea)}

The results for Site 768 are reported as descriptions below and as semiquantitative evaluations in Table 1 and Figure 3.

The organic facies Unit A ( 0 to $200 \mathrm{mbsf}$ ) is composed of minor to strongly dominant marine amorphous organic matter, sometimes diluted by strong to dominant terrestrial inputs including mainly opaque lignaceous fragments, spores, and pollen grains, fungus filaments, and rare cuticle fragments. Rare planktonic microfossils are also present (dinoflagellates, other nonidentified algae, chitinous foraminifers). The level of pyritization is moderate to strong, mainly appearing as framboids associated within the amorphous organic matter. This unit corresponds to the lithostratigraphic Unit I (pelagic foraminifer-nannofossil marls, interbedded with calcareous turbidites) and to the upper part of the Unit II (interbedded claystone, silty claystone, siltstone and some sandstone, with minor carbonate turbidites). Regarding the organic matter type, there is no clear difference indicating Unit I to Unit II transition, although the TOC values are lower in Unit I than in Unit II (Fig. 4).

The organic facies Unit B (200-500 mbsf) is composed of dominant to strongly dominant terrestrial organic matter, mainly including translucent lignaceous fragments, cuticles, spores, and pollen grains, and fungus filaments. Some marine amorphous organic matter is present especially in the upper part of the unit, while rare planktonic and benthic microfossils (algae, chitinous foraminifers, incertae cedis) can also be observed. The whole unit is characterized by a strong pyritization level appearing mainly as framboids (PI. 2.2). This organic facies unit corresponds to the middle part of the lithostratigraphic Unit II (mostly turbidites with minor hemipelagic facies, including interbedded claystone, silty claystone and siltstone).

The organic facies Unit C (500-750 mbsf) is composed of dominant to strongly dominant terrestrial organic matter, including mainly opaque and translucent lignaceous fragments and probably amorphous organic matter derived from lignaceous material. This terrestrial origin of AOM is assumed because of its current texture, which appears as aggregated small grains with the same color as the translucent lignaceous fragments. Planktonic microfossils are absent or very rare depending on the samples. The degree of pyritization is generally weak to moderate, mainly appearing as framboids except in the lower part of the unit in which many originally lignaceous fragments have been transformed in pyrite. This unit corresponds to the lower part of the lithostratigraphic Unit II and to the upper part of Unit III, both including major turbidite deposits with claystone, silty claystone, clayey siltstone and siltstone. The samples at 522.44 and 522.34 mbsf are typical of a turbidite sequence (Table $1, \mathrm{Pl}$. 2.3). The first was taken from the beginning of the sequence characterized

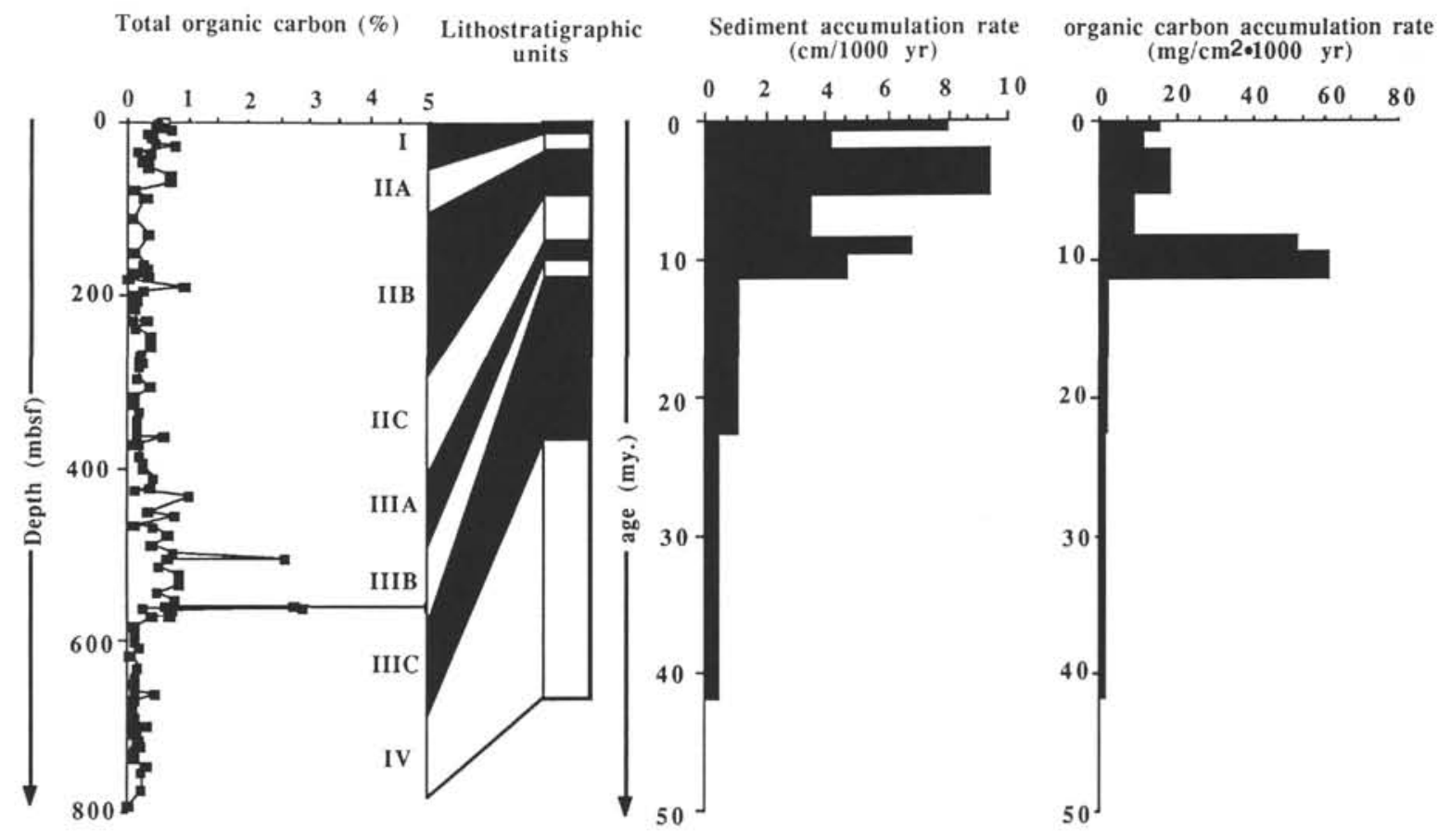

Figure 2. Sediment and total organic carbon accumulation rates vs. age in comparison with total organic carbon vs. depth at Site 767 (Celebes Sea). 


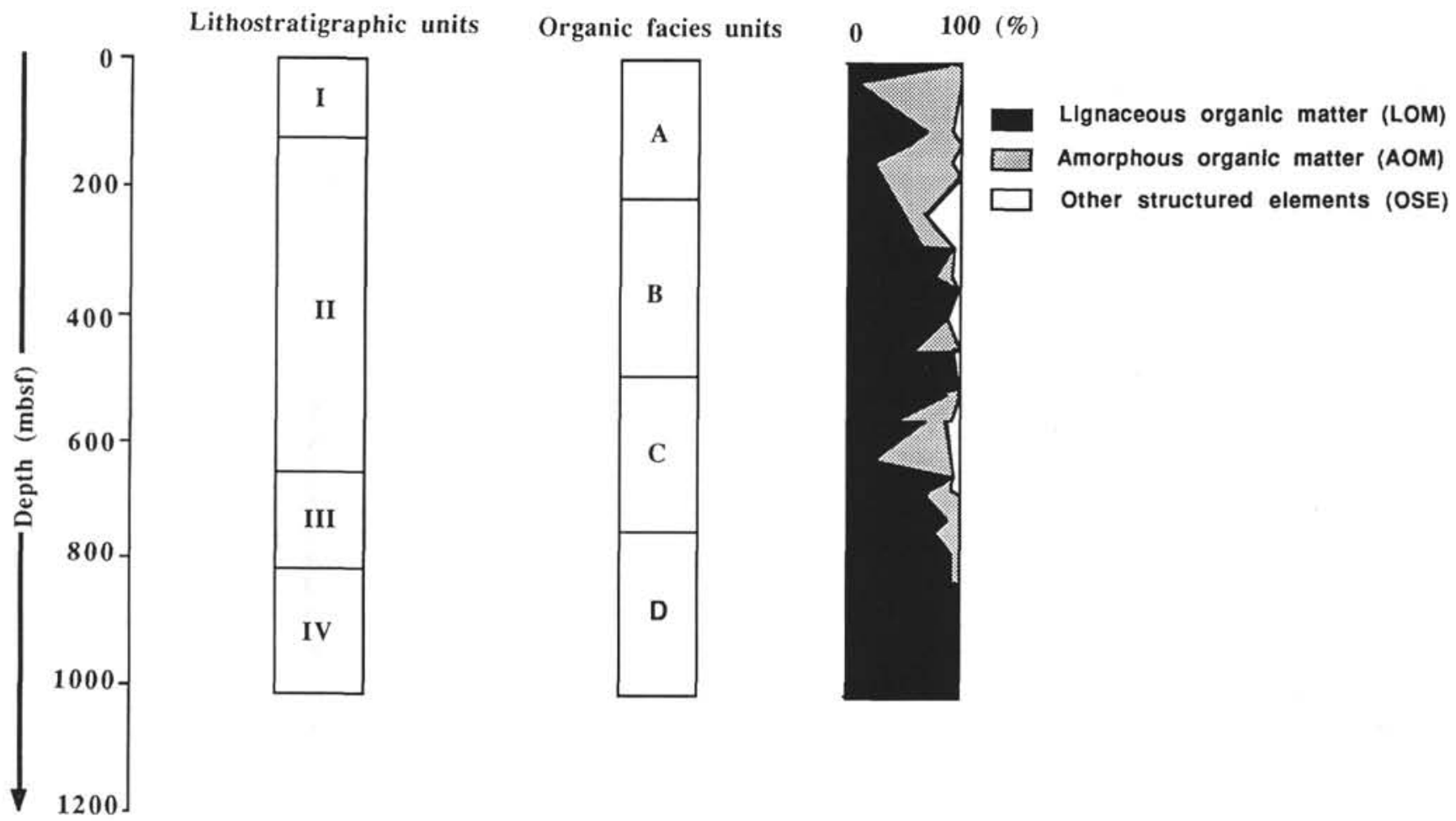

Figure 3. Organic facies units in comparison with the lithostratigraphic units at Site 768 (Sulu Sea).

Total organic carbon (\%) Lithostratigraphic Sediment accumulation rate

Organic carbon accumulation rate units $(\mathrm{cm} / 1000 \mathrm{yr})$ $\left(\mathrm{mg} / \mathrm{cm}^{2} \cdot 1000 \mathrm{yr}\right)$
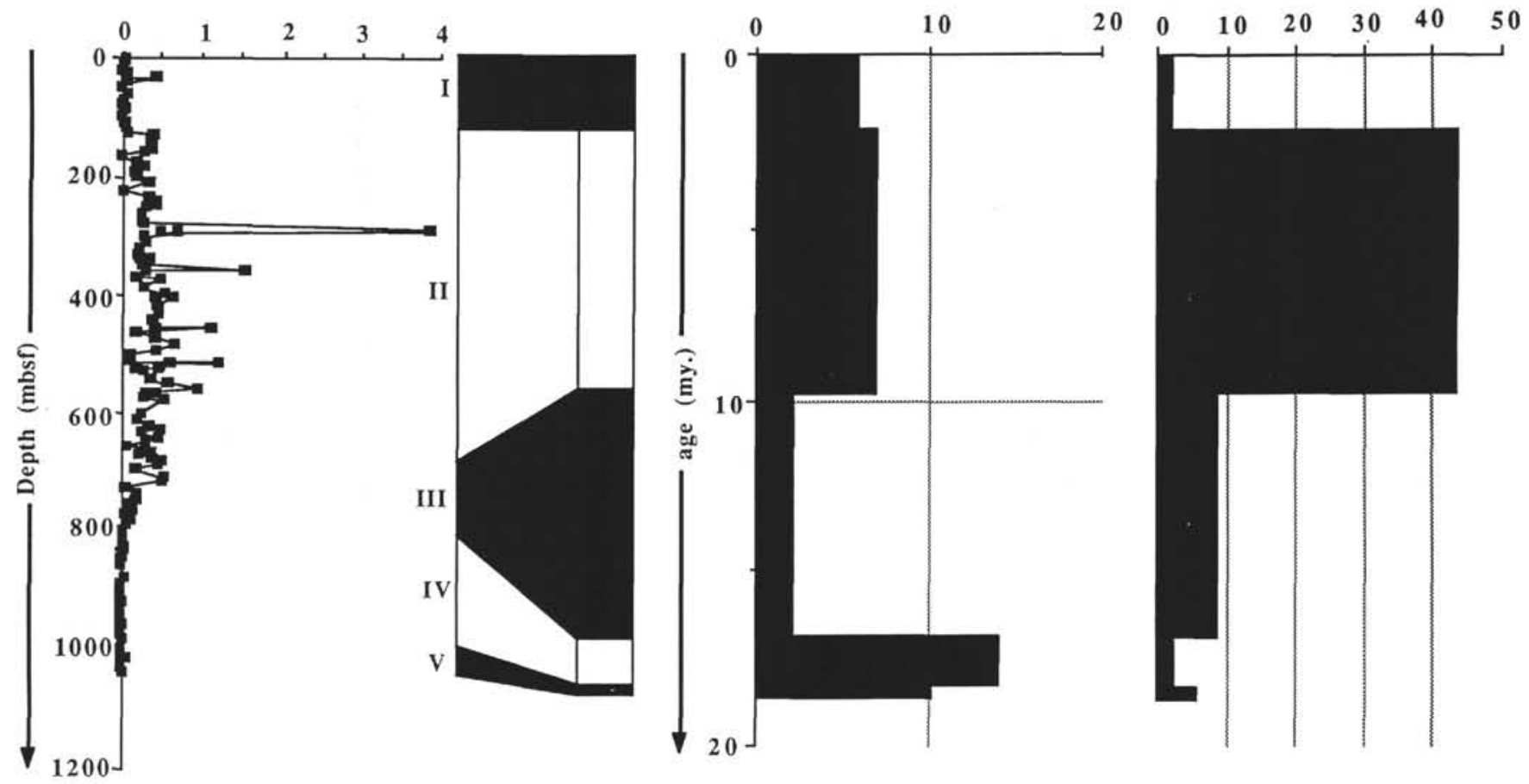

Figure 4. Sediment and total organic carbon accumulation rates vs. age in comparison with total organic carbon vs. depth at Site 768 (Sulu Sea). 
by a major siltstone lithology, while the second was taken from a later phase of the sequence, characterized by a major claystone lithology. At the beginning of the sequence, the turbiditic input is extremely dominant, with a low TOC and a exclusively terrestrial organic matter type (LOM and AOM). Later in the sequence, the TOC is higher with more AOM, also assumed to be of terrestrial origin because of its texture and color. Because of this origin, we think that the differences in the TOC values as well as in the petrographic composition of the organic matter were induced by selective deposition of the components of the initially reworked sediment along the turbidite sequence, rather than by dilution of hemipelagic inputs by turbiditic inputs. In these series dominated by turbidites, the autochtonous organic contribution (marine amorphous organic matter and planktonic and benthic microfossils) is probably too diluted to be observed whatever the position within a turbidite sequence may be.

The organic facies Unit D (750 mbsf down to the basement at $1046.6 \mathrm{mbsf}$ ) is strongly dominated by terrestrial organic matter mainly including small opaque lignaceous fragments. Some particles of AOM can be observed especially in the upper part of the unit. The pyrite is very rare or absent. This organic facies unit corresponds to the lower part of the lithostratigraphic Unit III (red brown claystone), to Unit IV (pyroclastic material) and to Unit V (interbedded dark brown claystone and greenish gray tuff).

\section{Early and Thermal Diagenetic Effects at Both Sites}

The vitrinite reflectance measurements $\left(R_{m}\right.$ values in Table 1$)$ indicate that the organic matter is immature from the top to the bottom of the Site 767 sedimentary column $\left(R_{m}<0.5 \%\right)$. The most reliable values were obtained from 350 to $680 \mathrm{mbsf}$ because of the good quality of the vitrinite at these levels (corresponding mainly to the lignaceous material observed in the organic facies Unit B). They indicate a $R_{m}$ gradient of $0.4 \% R_{m} / 1000$ that is over the random increase of vitrinite reflectance with depth (Robert, 1988). Therefore, if significant weight losses affected the TOC accumulation rates at Site 767 , they should be only due to early diagenetic processes.

The variations of the vitrinite reflectance with depth at Site 768 indicate a very high paleogeothermal gradient (Table 1). The organic matter is mature $\left(R_{m}>0.5 \%\right)$ below $500 \mathrm{mbsf}$. This interpretation is also supported by the $\mathrm{T}_{\max }$ measurements from the Rock Eval, by the composition and the stable isotope geochemistry of gasses (Rangin, Silver, von Breymann et al., 1990, Berner et al., 1990, Berner, unpublished data). In the major turbiditic series ( 400 to $750 \mathrm{mbsf}$ ) the $R_{m}$ values are the most reliable because of the good quality of vitrinite. These values indicate a $R_{m}$ gradient of approximately $1 \% / 1000 \mathrm{~m}$. Because of the thermal maturation of the organic matter observed at Site 768, especially below $500 \mathrm{mbsf}$, possible weight losses due to thermal transformations (catagenesis) should not be rejected as playing a significant role in the TOC accumulation rates.

\section{General Characteristics of the Organic Sedimentation at Site 767 (Celebes)}

The mean values of sediment and TOC accumulation rates vs. age (m.y.) are reported in comparison with individual values of TOC vs. depth (mbsf) in Figure 2 for Site 767.

Three major phases can be distinguished in the organic sedimentation of Site 767, broadly corresponding to the organic facies Units A, B, and C.

From approximately $42 \mathrm{~m} . \mathrm{y}$. (middle Eocene) to $11 \mathrm{~m} . \mathrm{y}$. (middle Miocene), the mean values of TOC accumulation rates have been very low $\left(\mathrm{mg} / \mathrm{cm}^{2} \cdot 1000 \mathrm{yr}\right)$, as have the sediment accumulation rates. The major lithology of the sediments is pelagic to hemipelagic (lithostratigraphic Units IV and IIIC) with very low contents of only terrestrial, highly degraded, organic matter. Due to its degradation and very small size, this organic matter is thought to come from distant sources. During this period, the metabolic organic material (notably the marine planktonic organic matter) was probably removed because of the oxic environment, as indicated by the brown to reddish brown pelagic claystone lithology. These observations are in agreement with an open-ocean environment that is the interpretation deduced from the general lithology (Rangin, Silver, von Breymann et al., 1990, Rangin et al., 1989) for this early phase of the Celebes Basin formation.

The second short period (11 to $9 \mathrm{~m} . \mathrm{y} .$, middle to late Miocene) is characterized by an abrupt change giving rise to high TOC accumulation rates $\left(>50 \mathrm{mg} / \mathrm{cm}^{2} \cdot 1000 \mathrm{yr}\right)$ that correspond to the major turbidite deposits of the lithostratigraphic Units IIIB and IIIA with high sediment accumulation rates. The organic sedimentation is therefore strongly dominated by the major contribution of turbidites enriched in terrestrial organic matter. The marine amorphous organic matter is extremely diluted, so its state of preservation cannot be accurately assessed. This phase may be due to a major compressive event between the Philippine Mobile Belt and the Sulu, Cagayan, and Palawan Ridges during the middle Miocene (Rangin, Silver, von Breymann et al., 1990, Rangin et al., 1989, Rangin et al., 1990).

From 9 m.y. up to the present (Units IIC to I), the TOC accumulation rates are lower than in the previous period $(<20$ $\mathrm{mg} / \mathrm{cm}^{2} \cdot 1000 \mathrm{yr}$ ) although the sediment accumulation rates are still high, even reaching a maximum for Site 767 in Unit IIB. In this interval, the composition of organic matter shows variations between a dominant marine amorphous organic matter and a dominant terrestrial organic matter that are probably due to the position of the considered levels within the minor carbonate and siltstone turbidites. The presence of levels dominated by marine amorphous organic matter shows that the organic sedimentation was drastically different than in the first period (Units IV and IIIC). This could be due to a higher productivity in surface waters resulting from the continental closeness, (and/or to better conditions for organic matter preservation). Units I to IIB cannot be characterized as anoxic facies. However, they indicate more reducing conditions at least in the sediment (moderate bioturbation, green to gray claystone, presence of pyrite) than Units IIIC and IV (strong bioturbation, brown to red claystone, no pyrite). This hypothesis would be in agreement with the more confined situation of the basin during the latest phase of its formation. We think also that, although intermittent, the supply of turbidites, rich in terrestrial organic matter, has acted to induce reducing conditions in the sediment for the whole period. The marine organic matter would have been at least partly preserved for the whole period because of rapid burial, but its relative abundance would have been controlled through dilution by intermittent turbidites.

\section{General Characteristics of the Organic Sedimentation at Site 768 (Sulu Sea)}

Even though the absolute values of TOC accumulation rate may have been affected by early diagenetic and thermal processes, four major phases of organic sedimentation can be recognized at Site 768 (Table 2 and Fig. 4).

From 18.7 to 9.8 m.y. (early to middle Miocene) the TOC accumulation rates are relatively low $\left(<10 \mathrm{mg} / \mathrm{cm}^{2} \cdot 1000 \mathrm{yr}\right)$ and the organic matter is composed of major terrestrial degraded fragments. This phase corresponds to the rapid opening of the Sulu Basin (Rangin et al., 1989, Rangin, Silver, von Breymann et al., 1990), recorded by the lithostratigraphic Units V, IV, and III, which are dominated by dark brown claystone, pyroclastic material, and normally graded beds of sandstone, siltstone, and claystone, respectively. Together with the major lithology, the degree of pyritization, which is generally weak, indicates poor conditions 
for organic matter preservation except in the upper part of the Site where amorphous organic matter is also observed. Although the low TOC can be partially explained by dilution of the mineral inputs (especially in the lower part of the sequence where the sediment accumulation rates are significantly higher) the size of organic particles indicates that the Site has been relatively isolated from the organic continental sources (Zamboanga) during the early Miocene, possibly due to the near Sulu Trench. This phase corresponds to the end of the open-ocean phase in the Celebes Sea.

From 9.8 to 2.1 m.y. (middle Miocene to late Pliocene), the organic sedimentation is characterized by high TOC accumulation rates ( $>40 \mathrm{mg} / \mathrm{cm}^{2} \cdot 1000 \mathrm{yr}$ ) with an organic matter mainly composed of terrestrial organic matter. This latter is a part of the major turbidite deposits of the lithostratigraphic Unit II, relatively similar to those observed in the Celebes Sea and corresponding to the same collisional event between the Philippine Mobile Belt and the Palawan, Cagayan, and Sulu ridges (Rangin et al., 1989, Rangin et al., in press). As in the Celebes Basin, the marine amorphous organic matter is extremely diluted so that its state of preservation cannot be accurately assessed. Because of its morphology and color, the amorphous organic matter observed in this interval (Table 1) is assumed to be mainly derived from terrestrial organic matter that was altered through bacterial activity.

From 2.1 m.y. to the present, the TOC accumulation rates decrease again to low values $\left(<5 \mathrm{mg} / \mathrm{cm}^{2} \cdot 1000 \mathrm{yr}\right)$ with major amorphous organic matter or major terrestrial organic matter depending on the levels. This phase corresponds to the lithostratigraphic Unit I, which is characterized by nannofossil marls. The Unit II (major green clays) to Unit I (nannofossil marls) phase transition is a major change in the general sedimentation of the Sulu Sea, probably indicating a rapid shallowing of the surrounding sills, protecting the basin from the deep waters of the Pacific (Rangin et al., 1989). However, taking into account the variations of the individual TOC values (Fig. 4) and of the petrographic type of the organic matter (Table 1, Fig. 3), this lithostratigraphic change does not appear to be directly related to any organic sedimentation change. The organic facies of Site 768 (Table 1, Fig. 3) indicate a change in conditions for organic matter preservation through the relative proportion of AOM and the degree of pyritization. More reducing conditions in the sediment are indicated as early as Unit III phase (middle Miocene) and were probably due to an increase in terrestrial organic matter supply via turbidites.

\section{ACKNOWLEDGMENTS}

We are indebted to the Ocean Drilling Program for providing samples, to the Centre National de la Recherche Scientifique, and to the Deutsche Forschungsgemeinschaft for financially supporting the shore-based studies in Orléans and in Hannover, respectively. Technical assistance by Françoise Champion and Jean Simonato is also gratefully acknowledged.

\section{REFERENCES}

Berggren, W. A., Kent, D. V., Flynn, J. J., and Van Couvering, J. A., 1985. Cenozoic geochronology. Geol. Soc. Am. Bull., 96:1407-1418.

Berner, U., Bertrand, P., and Scientific Party of Leg 124, in press. Evaluation of the paleogeothermal gradient at Site 768 (Sulu Sea). Geophys. Res. Lett.

Bertrand, P., Lallier-Vergès, E., Grall, H., 1991. Organic petrology of Neogene sediments from north Indian Ocean (Ocean Drilling Program, Leg 117): Amount, type, and preservation of organic matter. Proc. ODP, Sci. Results, 117: College Station, TX (Ocean Drilling Program), 587-594.

Emeis, K. C., and Kvenvolden, K. A. (1986). Shipboard organic geochemistry on Joides Resolution. Technical Note No. 7 (Ocean Drilling Program).

International Committee for Coal Petrology.International Handbook of Coal Petrography, 2nd ed. 1963. Reprinted 1985. 1st supplement to 2nd ed., 1971, reprinted 1985. 2nd suppl. to 2nd ed., 1975. Paris (Centre National de la Recherche Scientifique).

Rangin, C., Pubellier, M., et al., 1990. The quest for Thethys in the western Pacific. 8 paleogeodynamics maps for Cenozoic. Bull. Soc. Geol. France, 8 Serie, Tome 6:901-913.

Rangin, C., Silver, E. et al., 1989. Forages dans les bassins marginaux du SE asiatique: résultats préliminaires du Leg 124 (Ocean Drilling Program). C. R. Acad. Sc., Paris,309(II):1333-1339.

Rangin., C., Silver, E., von Breymann, M. T. et al., 1990. Proc. ODP. Init. Repts., 124: College Station, TX (Ocean Drilling Program).

Robert, P., 1988. Organic Metamorphism and Geothermal History. Microscopic Study of Organic Matter and Thermal Evolution of Sedimentary Basins: Amsterdam (Elf-Aquitaine and D. Reidel).

Date of initial receipt: 17 May 1990

Date of acceptance: 3 October 1990

Ms 124B-155 


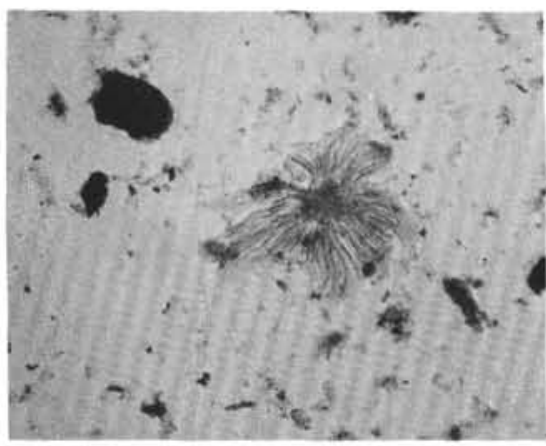

1

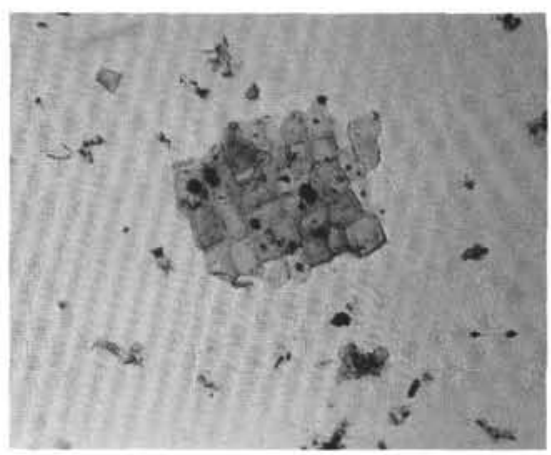

3

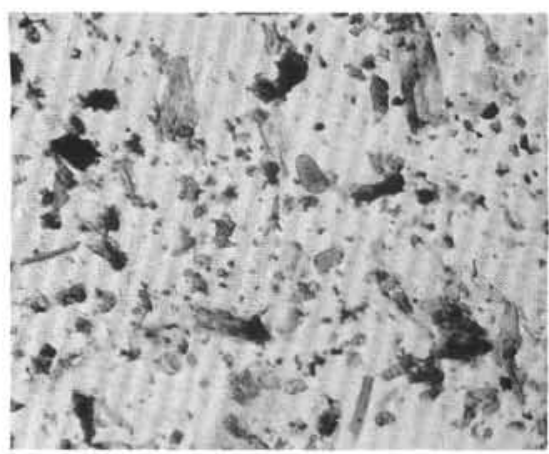

5

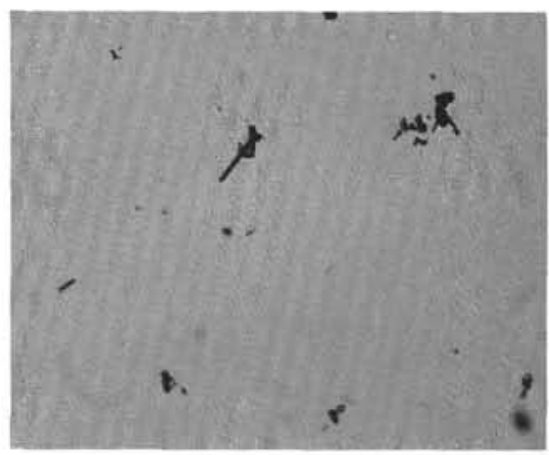

7

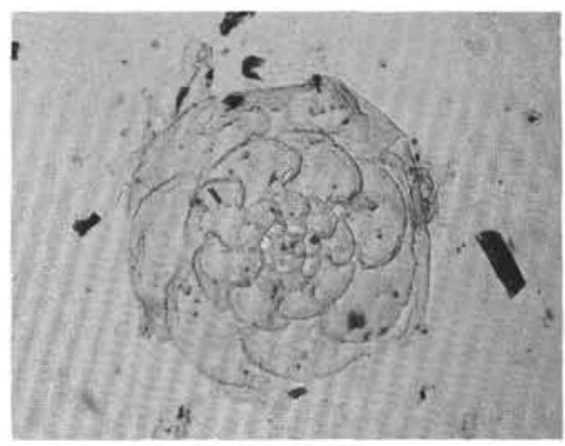

2

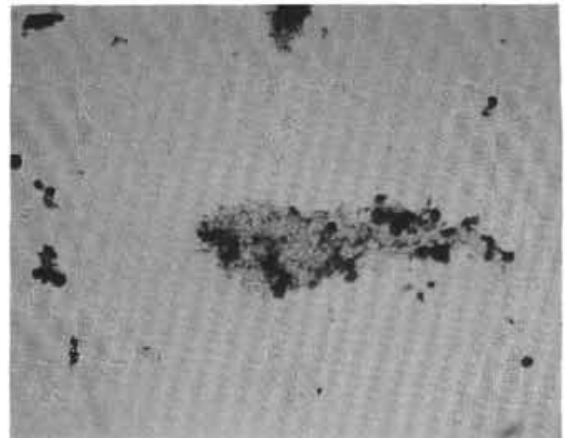

4

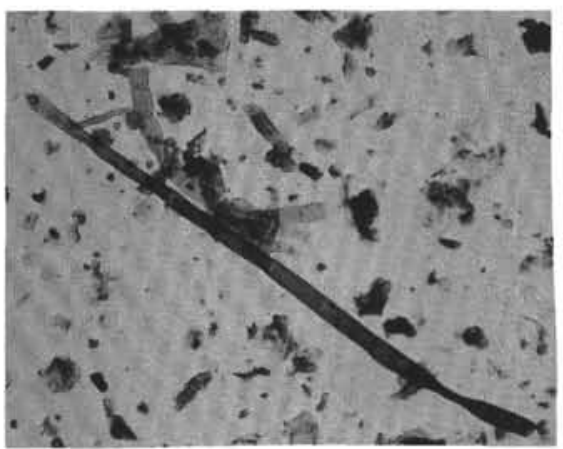

6

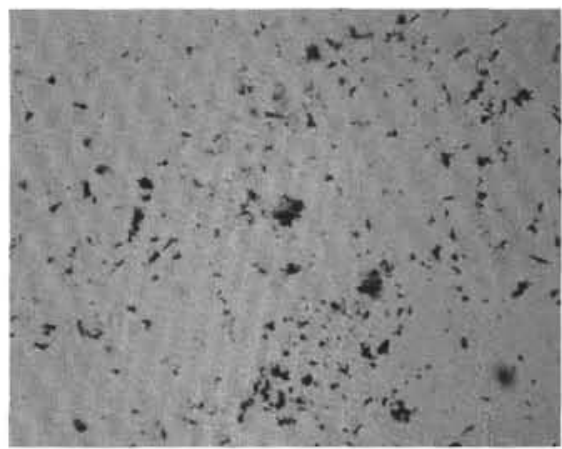

8

$20 \mu \mathrm{m}$

Plate 1. Organic components from the Celebes Sea (Site 767) observed in transmitted light (second residue). 1. Small-sized amorphous organic matter and planktonic marine microfossil. Sample 124-767A-1H-CC, 11-16 cm. 2. Microforaminifer. Sample 124-767A-1H-1, $23-28 \mathrm{~cm}$. 3. Cuticle fragment with pyrite. Sample 124-767B-35X-1, 69-71 cm. 4. Amorphous organic matter with pyrite. Sample 124-767B-40X-4, 0-3 cm. 5. Terrestrial organic matter with dominant lignaceous fragments. Sample 124-767B-45X-CC, 49-52 cm. 6. Terrestrial organic matter with dominant lignaceous fragments and fungus filaments. Sample 124-767B$61 X-2,31-34 \mathrm{~cm}$. 7. Small-sized degraded terrestrial organic matter. Sample 124-767B-72X-4, 90-93 cm. 8. Small-sized degraded terrestrial organic material. Sample 124-767B-8R-1, 67-71 cm. 


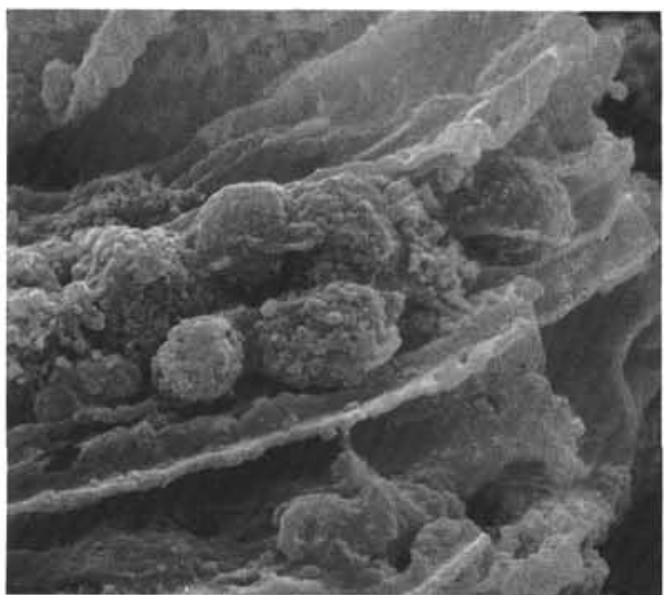

1

$10 \mu \mathrm{m}$

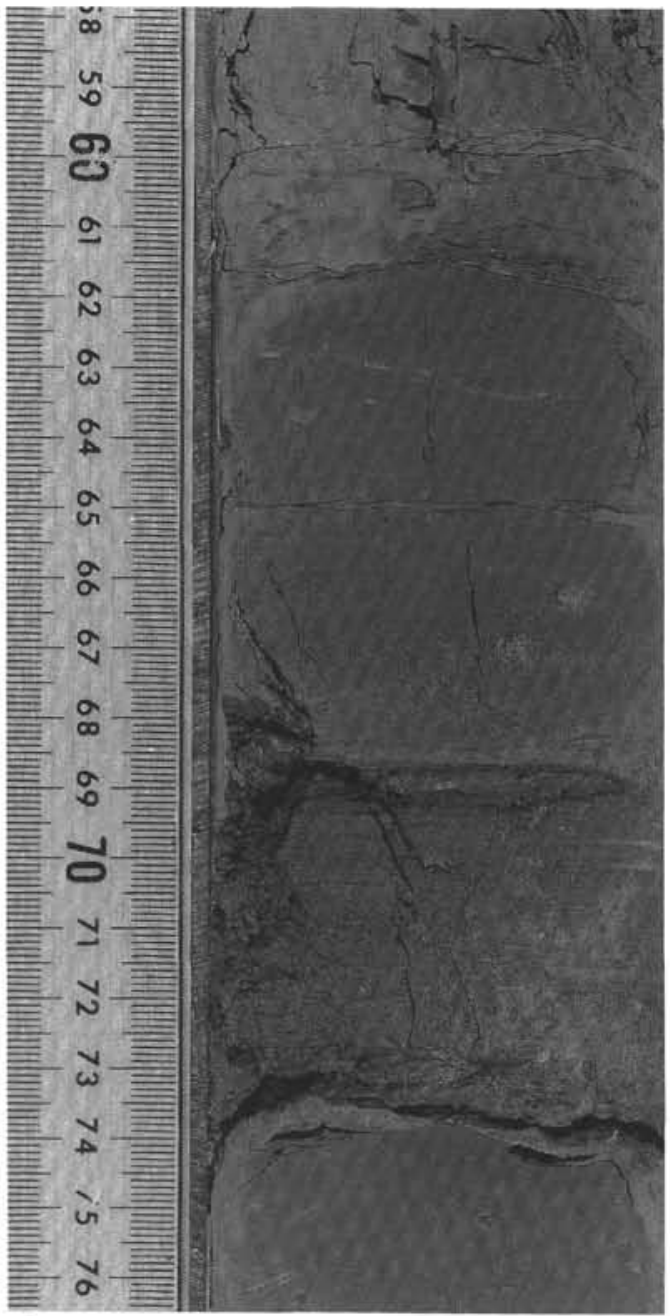

3

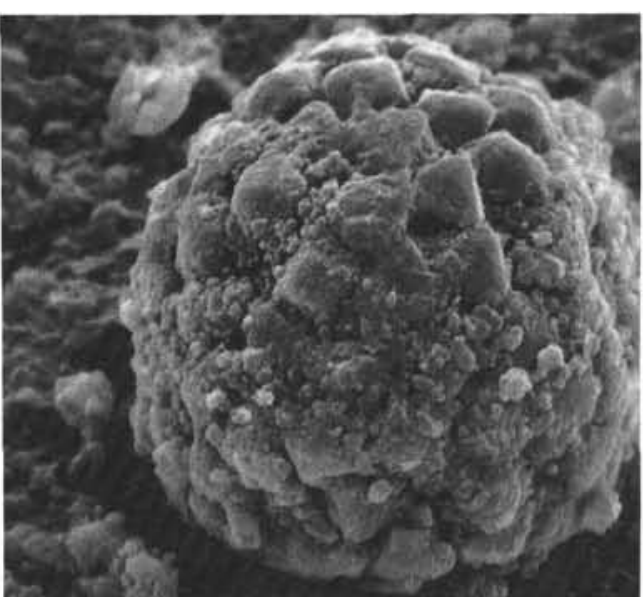

2

$20 \mu \mathrm{m}$
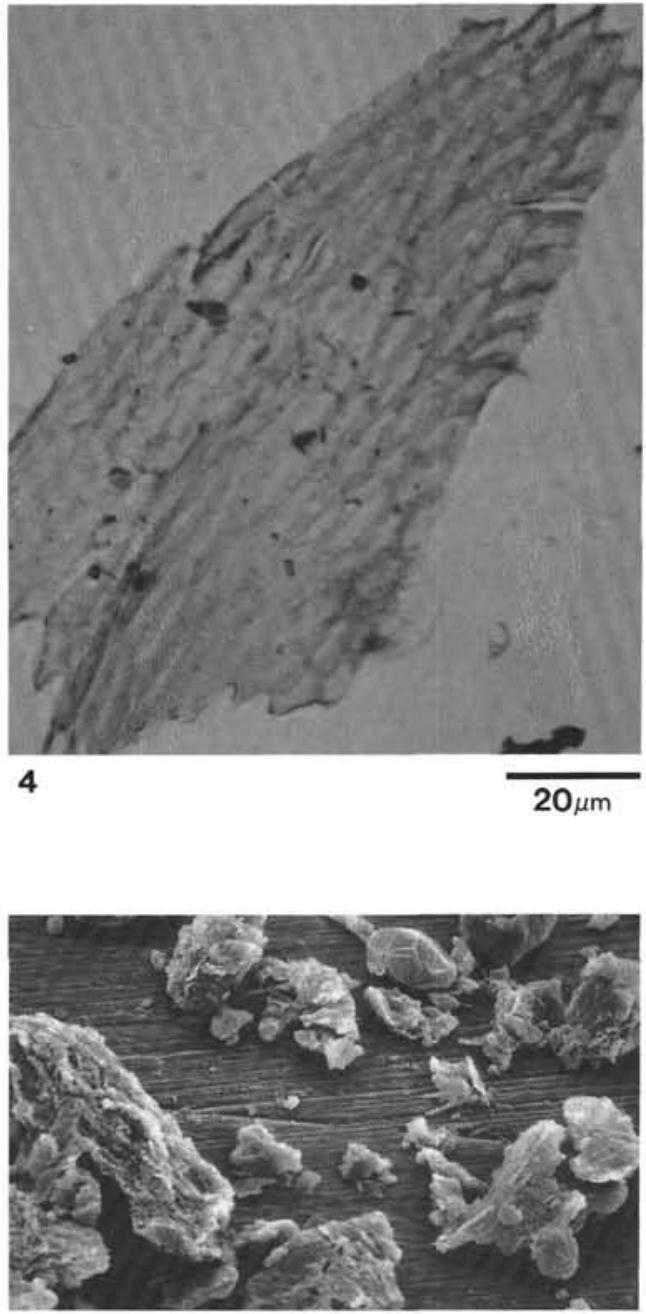

5

$100 \mu \mathrm{m}$

Plate 2. 1. Lignaceous fragment with pyrite framboids observed in SEM. Sample 124-767B-25X-4, 76-78 cm. 2. Pyrite framboid observed in SEM. Sample $124-768 \mathrm{C}-6 \mathrm{R}-2,20-23 \mathrm{~cm}$. 3. Core photograph showing a normal graded turbidite sequence from siltstone to claystone. Sample 124-768C-18R-4, 58-77 cm. 4. Cuticle fragment observed in transmitted-light microscopy. Sample $124-768 \mathrm{C}-18 \mathrm{R}-4,62-66 \mathrm{~cm}$. 5. Terrestrial organic matter with dominant lignaceous fragments observed in SEM. Sample 124-768C-18R-4, 62-66 cm. 